Mi adja meg az élet értelmét? A kérdésre - a számvetést készítoo öregek sajátos filozófiájával - sosem hallott paraszti ,,ars poeticákban" fogalmazód nak meg a válaszok. Nemcsak a néprajzosokhoz szól, s nemcsak a vásárhelyieké ez a könyv. Amit irója vállalt: az emlékezettel még éppen elérhetố parasztmúlt emberi értékeinek átmentése. Ěrtük és általuk, akik sorsként élték meg azt - mindannyiunknak, hogy merítsünk belöle. Mert az üzenet így hangzik: ,A mi sorsunk a halálunkkal lezárul, de mégis folytatódik tovább, mert gyerökök születtek. A szülók, az embörök a gyerö. keikben élnek majd tovább." (338. o.)

Legyen ez ajánlás valamennyi társadalomkutató számára.

Duró Annamária

\title{
FRISNYÁK SÁNDOR: TÖRTÉNETI FÖLDRAJZ
}

\author{
(Szabolcs-Szatmár megyei Pedagógus Továbbképzó Intézet; Nyíregyháza, 1985. 390 p.)
}

A könyv a szerző „Adalékok a SzatmárBeregi síkság, a Rétköz, a Nyirség és a Zempléni-hegység történeti földrajzához (XVIIIXIX. század)" c. kandidátusi ér tekezése alapján készült. A vizsgált mintaterületek eltérő jellege (alföldi és hegységi) módot ad annak bemutatására, hogy a különböző környezettípusok mint a társadalmi termelés állandó és szükségszerú feltételei - többféle termelési-gazdasági tér kialakulását segítették elő. Az, ,időkeresztmetszet" (a XVIII-XIX. század) kiválasztását a földrajzi környezet átalakulásának felgyorsulása, a természeti képben és a társadalmi-gazdasági szférában bekövetkezett változások magyarázzák.

A történeti földrajznak két ága van. Az egyik a topográfiai rekonstrukció, amellyel a historikusok foglalkoznak. Ez a jelenségek és folyamatok térbeli regisztrálására törekszik. A geográfusok által müvelt önálló történeti földrajz feladata a földrajzi környezet (valamely szintû regionális egység) múltbeli állapotának komplex geográfiai feltárása és értékelése. A történeti földrajz - véli a szerző - a gazdaságföldrajz önálló tudományága, ugyanúgy mint az ipar-, az agrár-, a településföldrajz stb. Azonban Magyarországon a történeti földrajz mindmáig kevésbé múvelt tudomány, s e müfajban elért eredmények nagy része a történészek érdeme. Magyarország történeti földrajzának feldolgozása a makroregionális vizsgálatok eredményeire kell hogy épüljön. Mivel nagytáj-szintü történeti földrajzi munkák még nem állnak rendelkezésre, mezo- és mikrotér ségek kutatása látszik reális feladatnak. Ennek a koncepciónak az értelmében született meg ez a munka is. A szerző kutatásai során a források széles körét használta fel, köztük elsôsorban a történeti földrajz speciális forrásait (írott emlékek, íratlan szellemi hagyatékok, földrajzi nevek, régi kéziratos és nyomtatott térképek, látképek, rajzok, fényképek, tárgyi emlékek). A forrásanyag feldolgozása során alkalmazni kellett a történeti földrajzban ismert metodikai eljárásokat, így a reduktiv (egyszerüsítô), a retrospektív (visszaf lé vizsgáló), retrogressziv (visszaf elé haladó) és különösen a komparativ (összehasonlító) módszert. Ez utóbbi lehetôvé teszi, hogy egy-egy korszak értékelése ne szakadjon el az akkor adott fejlődési színvonaltól, az akkori társadalmi, gazdasági és politikai hatótényezôktốl.

A könyv a földrajztudományban klasszikusan alkalmazott logikai menetet követi. Első érdemi fejezete az említett területek XVIII. századi ősi, folyószabályozás és belvízrendezés elốtti állapotát tárja elénk. Az olvasó sok érdekességet, részletekre is kiterjedô leírást, korabeli rajzolt térképeket talál e vidékek XVIII. századi természetföldrajzi és elsősorban hidrogeográfiai képéről. Nagyon karakteresen jelentkezik a társadalom természetátalakító szerepe és ereje a XIX. század folyamán az alföldi térségek példáján (belvízrendezés, folyószabályozás stb.). A hegyvidéki mintaterület természetföldrajzi képe az egymásra épülő kultúrák nyomán kisebb változáson ment keresztül, mint síksági környezete.

A következőkben a szerzó a termelés társadalmi-gazdasági feltételeit elemzi, elhelyezi a térséget a vizsgált idôszak szükebb és tágabb 
ga zdasági térszerkezetében. A termelöerök területi elhelyezkedésének során vizsgálja a terület népesség- és településföldrajzát, ennek változásait. A XVIII. század időszakában, a török kiûzése után indul meg a népesség belső migrációja és az idegenek betelepedése. A fölszabadított földekre a különböző adózási és robotkedvezmények reményében kárpátukránok (ruténok), szlovákok, németek és románok is érkeztek a magyarok mellett. Rendkiviul érdekes képet mutat Nyíregyháza népességének nemzetiségi megoszlása, hiszen 1850-ben a magyarok aránya még alig egyharmad, 40 évvel később már $80 \%$ feletti, 1930-ra pedig gyakorlatilag tiszta magyar a város népessége. $\mathrm{A}$ terület településviszonyai sajátos kettősséget mutatnak, mivel a Nyugat-Nyírség és a Mezőség településhálózata a XVI-XVII. században elpusztult, de a megye többi részén, a Rakamaz-Nyíregyháza és Nyírbátor vonaltól keletre esổ területeken a falvak és mezôvárosok életfolytonossága nem szakadt meg. Az elpusztult települések helyén a XVII-XVIII. században nagyfalvas tanyás települések (óriásfalvak) alakultak ki. A Nyírség keleti felén és a Rétközben közepes nagyságú falvak, a Szatmár-Beregi síkságon a középkori eredetú aprófalvak a jellemzőek. Korabeli, kétbeltelkes (,,kertes") településeket, települések belterületeit, nyirségi bokortanyák alaprajzi típusait ábrázoló térképek sora egészíti ki és ill usz trálja a leírtakat.

A szerzónek igaza van abban, hogy az alföldi és hegyvidéki területet a gazdaság elemzése során is külön kell választani. Az elöbbi tipikus agrárvidék, ahol a XVIII. század folyamán a földrajzi munkamegosztás még jelentéktelen, éppen ezért a termelőegységek önellátó gazdaságok voltak. Fontos kutatási eredmény, amit a szerzô az ún. fok-gazdálkodásról ír. „A folyókat kísérö, néhány m-rel kiemelkedő hátak árvízmentes térszínét a folyó partjait megszakító nyílások, a fokok (erek) tagolták. A természetes vagy mesterséges fokokon kitörő víz a mélyebb fekvésû (ár-) területekre ömlött, majd apadáskor ezeken az ereken a folyómederbe nagyrész $t$ visszaáramlott. A több méter széles erek feudális kori ártérgazdálkodás alapjai voltak (halászat, vízi szállítás, energiahasznosítás stb.)." (78. oldal). Részle tes leírást kapunk a növénytermesztés és állattenyésztés különböző, itt jelentős ágazatairól és ezek területi elhelyezkedéséröl. A hegységi területen a változatosabb és gazdagabb természeti erőforrások már a XVIII. századtól lehetôvé tették az önellátó agrárgazdálkodás kereteinek megbontását. $\mathrm{Az}$ árutermelö Tokaj-Hegyaljai szölőmúvelés mellett a Zempléni-hegység területén a bányászat, az ipar is megtalálható, és megindul a feudális céhszervezeteket felváltó manufaktúrák szerveződése is. A térség manufaktúraiparát az üveg- és keménycserépgyártás, a fafeldolgozás és az élelmiszeripar jellemzi. ,A táj (és egyben Magyarország) első porcelángyára a regéci uradalomban, Telkibányán épült 1825-ben." (101. oldal). A mezôgazdaság az intenzív földhasznosításra (a szólô- és gyümölcstermelésre), a szántógazdálkodásra és a halászatra, illetve az extenzív állattartásra épül. A vizsgált terület, vagyis a Felsö-Tiszavidék, a Nyírség és a Zempléni-hegység közlekedési centruma a tokaji átkelóhely volt, melyet a korabeli térképek alapján lehet rekonstruálni. Ennek az ösi Tisza-révnek, illetve hídnak különleges helyzete volt a XVIII-XIX. századi áru- és személyforgalomban, a külső helységkeret és a belső medencecsoport gazdasági kapcsolatában. Azonban csak a XIX. század második felében, a korszerú közlekedési (vasút-) hálózat kiépülésével valósult meg e vidéken a területi munkamegosztás. A könyvet német nyelvü összefoglalás és gazdag forrásanyag zárja.

Ezt a munkát olvasva felmerül: jó lenne, ha a két tudomány közötti kapcsolat nyújtotta lehetőségeket jobban kihasználnánk, hiszen ELISÉE RECLUS frappáns megfogalmazása szerint: a földrajz térbeli történelem, a történelem pedig idôbeli földrajz. Ennek jegyében ajánlom a könyvet minden történelem iránt érdeklődő geográfusnak és földrajz iránt érdeklődő történésznek.

Horváth János 